several hundred feet, using the form of coherer described, and, therefore, I am unable to compare its sensibility with that of the usual form.

Undoubtedly it would prove to be less sensitive, but for use over a moderate distance it forms a convenient instrument for the purpose of demonstration.

University of Wisconsin, U.S.A.

\section{Secondary Sexual Characters and the Coloration of the Prong-buck.}

THE weak spot in Mr. Cunningham's argument (NATURE, November 8, p. 29) lies in his believing it to be conceder' that secondary sexual characters which are the outcome of male katabolism need no explanation by the theory of sexual or of natural selection. Starting with this assumption, he points out that, since these characters are often not developed, male katabolism does not exist in such cases, or exists without producing any visible effects. He therefore rejects male katabolism as the cause of the variations and introduces in its stead "nervous and muscular activity" and "the habits of life and external conditions.

Whether Mr. Cunningham's hypothesis is an improvement upon that of Geddes and Thomson or Wallace may be doubted and, so far as his views are intelligible to me from the brief epitome his letter contains, they labour under the disadvantage of involving an acceptance in the Lamarckian doctrine and the transmission of acquired characters-problems which, seductive and important though they be, are as yet insufficiently supported by evidence and, whether true or false, stand aside from the Darwinian theory, neither refuting nor confirming it.

After all, "male katabolism," " metabolism" and " physiological activities" are in this connection merely names assigned to the unknown primary cause of certain male characters, and, as such, are nothing but imposing substitutes for the "vital force" of the pseudoscientific realists.

Setting on one side the question of the initial cause of variation, I am quite unable to agree with $\mathrm{Mr}$. Cunningham that secondary sexual characters may reach a high standard of perfection and be maintained in a state of stability by "physiological processes" without the controlling influences involved in the struggle for existence. Sexual variations, once started, must fall, like other variations, under the influence of external conditions; those which are harmful will be eliminated; those which are beneficial selected and preserved. Therefore, considering the diversity of the conditions under which species live, the needs that have to be satisfied, the enemies that have to be avoided, it is no matter for surprise that, even in the males of closely allied forms, the sexual characters vary in degree of manifestation, are sometimes suppressed, sometimes developed; or, taking the particular case Mr. Cunningham mentions, that the nigrescence of the bull kudu and nilghaie may, as I have suggested, be checked for purposes of concealment in the one and emphasised as an ornament or advertisement in the other.

One or two points in Mr. Cockerell's criticism of a footnote (NATURE, October I 5, p. 58) call for comment. His suggestion that $\mathrm{Mr}$. Wallace cites the prong-buck as an instance of recognition-marks in the sense in which these terms were employed in my article is inexact; and his opinion that I completely overlooked the point of a theory I was not discussing is, I can assure him, erroneous. Moreover, in spite of his incredulity, I venture to repeat that the prong-buck, with its white belly and darker upper side, is an illustration of Thayer's principle. That its patterns are to be explained exclusively on this principle I did not assert. With regard to Mr. Cockerell's reasons for rejecting the view that the prong-buck is procryptically coloured, I would commend the following facts to his consideration. Zebras and giraffes can be "seen from afar off in herds," they seek "safety in flight," and they have the same " necessity for keeping together when in flight "that the prong-bucks have. Nevertheless, these animals are known to be procryptically coloured, though the fact is by no means always evident to those who "have had the pleasure of seeing them in their native wilds."

November 18

\section{A New Race of Musk-Ox.}

Mr. ROWLAND WARD has on view at his establishment in Piccadilly a mounted adult male and female musk-ox from East Gr eenland, which differ from the ordinary form in having a large NO. 1624 , voL. 63$]$ whitish patch on the face, as well as in certain other details of coloration. They may be made the types of a new race, under the name Ovibos moschatus zvardi. The female was recently exhibited at the Zoological Society.

Harpenden, December Io.

The Optics of Acuteness of Sight.

IN reference to the letter of Mr. Percival in your issue of November 22 (p. 82), concerning acuteness of vision, it is interesting to determine the power of resolution of the eye considered as a lens merely, according to the well-known rule,

$$
\theta=\frac{\lambda}{\mathrm{A}} \times 2 \cdot 44 \text {. }
$$

Where $\theta$ is the angular diameter subtended at the second nodal point by the first dark ring of the diffraction image of a distant point, $\mathrm{A}$ is the aperture of the lens, and $\lambda$ is the wavelength of the radiations (supposed homogeneous) from the distant point.

Taking $\mathrm{A}$ for the eye as $4 \mathrm{~mm}$., and $\lambda$ as $0.000589 \mathrm{~mm}$. (yellow light) the value $\theta=I^{\prime} 2^{\prime}$ is obtained.

Hence the diffraction image of a luminous point on the retina may be taken as rather less than $I^{\prime}$ in angular diameter (the brightness of the diffraction disc rapidly decreasing towards the first dark ring).

It would thus seem that, should any considerable superiority of acuteness of vision exist among savages the cause should be looked for in the aperture of the iris, as well as in greater detail of the retina. F. TWYMAN.

54, Haverstock Hill, London, N.W., November 26.

\section{Euclid i. 32 Corr.}

With reference to Mr. Allman's letter in NAtuRe of November 29, the following will, I think, be of interest.

In Proclus' (4II-485 A.D.) commentary printed at the end of the Editio Princeps of Euclid (Grynaeus-Bâle, I533 A.D.) these two corollaries are given :-

(I) The sum of the interior angles of any polygon is equal to twice as many right angles as the polygon has sides less two.

(2) The sum of the exterior angles of any polygon is equal to four right angles. STAM. EUMORFopoulos.

33, Gloucester Square, Hyde Park, W., December 3.

\section{A PLEA FOR THE STUDY OF THE NATIVE RACES IN SOUTH AFRICA.}

$\mathrm{I} \mathrm{N}$ a recently-published work Dr. P. Topinard makes the statement that ethnography is cultivated in England because it leads to a knowledge of the natives, and thus prepares the means of turning them to account. This distinguished French anthropologist appears to have permitted his dispassionate judgment to have temporarily forsaken him. Alas! ethnography is but little cultivated in this country, and it may be said to be almost entirely neglected by our Government. It was to take away this reproach in some measure, and to seize the present opportunity in South Africa, that led Mr. E. Sidney Hartland, the President of the Folklore Society, to read before the Anthropological Section of the British Association at Bradford a very carefully considered and temperate paper, "On the Imperfection of our Knowledye of the Black Races of the Transvaal and Orange River Colonies."

Mr. Hartland stated that on the pacification of these colonies one of the first problems confronting us would be the management of the native black population. This led to the question, What did we know of the African races of these provinces? It must be confessed that we knew very little. Our hunters had hunted big game through the land; our missionaries had taught the natives; our traders had traded with black and white; our soldiers had fought in the country, and during the last twenty years mining adventurers had exploited the mineral products. None of these, except the missionaries, had had any real interest in the natives; consequently, few of the others had recorded anything of value 
concerning them. The records by the missionaries had been for the most part scrappy, and, from a scientific point of view, not to be implicitly trusted. But the blame for this did not rest entirely on the missionaries. The gap which the missionaries found between the savage mind and their own was unexpectedly wide, and this rendered it difficult for them to understand the natives, as well as for the natives to understand them. Moreover, what the missionary learnt of the native manners and customs he did not think it becoming to publish. Moffat had said that a description of these things would not be instructive or edifying. In the interests of science and government, it was much to be regretted that he and other missionaries had taken this view. Later missionaries had given us more information; John Mackenzie and Livingstone's books contained much of value, but were incomplete, and not always exact. One other reason of our defective knowledge of the customs of the black people was that, until the country was settled by the Boers, there was a state of intermittent warfare, which frequently resulted in the extermination of whole tribes.

There was among the various tribes a general similarity of institutions, customs and belief, but this similarity was by no means uniform. In the Umzimkulu district of Kaffraria all additions to, and alterations of, laws were made by the chief and councils at Great Place. Among the Galekas, Fingoes and Basutos, laws could be altered after the fashion familiar to us in England as "Judge-made law." Conservative as the natives were, the fact that there were recognised ways of making changes implied that such changes were effected, and that differences existed. In the matter of theft the punishments inflicted varied among the different tribes. Property stolen from the chief was punished more severely; in Bechuanaland restitution was required to be made. It was also pointed out that there were difficult questions respecting marriage and inheritance. The prohibited degrees seemed to be in one direction much wider than with us. In general throughout South Africa all blood relationship, which wastrecognised as such, was an absolute bar to marriage. Among one tribe such a marriage was dissolved, and a heavy penalty inflicted on the man. Among another tribe the only question was how much the man was willing to pay. Some tribes permitted a man to be married to two sisters, both living. Most of the tribes were polygamists. This fact rendered family arrangements very complex, and most of the questions coming before the courts were questions of inheritance. Wives of a native polygamist were not equal in rank. There was a great wife and a right hand wife, and most of the tribes recognised a left hand wife. Among few tribes could a woman inherit property. The Basutos were among the few. In general women, though not themselves property, were in a state of tutelage, and so incapable of either holding or inheriting property. It was easy to understand that the large number of tribes in South Africa would furnish an interminable example of difference of custom. Cases of theft often came before the courts; in some districts cases of inheritance were very common; while cases relating to marriage were always important, because status and inheritance depended on marriage, and such questions were frequent subjects of judicial decision.

One of the modes of oppression of natives in the Transvaal, Mr. Hartland proceeded to observe, had been the refusal to recognise any of their marriages. This was a policy we should be compelled to reverse. In order to do so we must start by informing ourselves what marriages were regarded by the natives of each tribe as legal, lest in our hasty zeal for justice we inflicted injustice. This information could only be obtained by careful inquiry on the spot. A bride-price was usually paid for the bride, but it was not always given. In nearly all tribes, however, it was a necessary incident of the most honourable form of marriage. A bride for whom no price had been paid felt very much as in this country a strict Churchwoman would feel if she were forced to be married at a registrar's office. A wife for whom no price had been paid would be reminded of the fact every time she quarrelled with her neighbours or with one of her fellow-wives, or even with her husband. Twenty years ago the Cape Government came to the conclusion that it ought, both for legislative and administrative purposes, to learn something about the native customs and institutions. The report of that Commission was perhaps the most valuable document we possessed on the black races of South Africa, and must form the basis of any inquiry our Government might make into the customs of the native races of the Transvaal and the Orange River Colony. Une of the difficult problems discussed by the Commission was that of the brideprice, known as Lobola or Ukulobola, and the question was whether the transaction was a bargain and sale of the bride, and, therefore, according to our law, immoral, or, if not, what it was? A Church missionary of twentythree years' experience described it as being the "direct sale of the girl in its purest state," and a Wesleyan minister said it was the "root of heathenism." On the other hand, Archdeacon Waters and Dr. Calloway, Bishop of St. John's, had, however, expressed their opinion in favour of the custom, holding that the payment was a pledge for the good treatment of the woman, and a pledge of her good conduct.

It was established by the Commission that the custom of lobola was not a purchase of the bride, but a substantial guarantee for her good conduct and good treatment. But the inquiry showed that Europeans, even if experienced in native ways, were often incapable, from prejudice or ignorance, of penetrating below the surface to the real meaning of a custom. Some who gave evidence could not distinguish between slavery and tutelage, and in their view every Roman matron would have been a slave.

It must be remembered that we could not civilise the savage all at once, and with a veneer of civilisation he would be more dangerous than before, for he would accept only its sweets and reject its bitters. The subject of beliefs was not less important than that of customs. We ought to govern the native races according to their own laws, and not by ours. We should remember that if we had so much difficulty in understanding their laws, it was no wonder they had similar difficulty in understanding ours. They were, as a missionary told the Commission, so much attached to their customs, and their customs were so much a part of themselves, that they could not imagine any others. An accurate study of the native customs, institutions and beliefs was an urgent necessity both for missionnries and for purposes of government.

Now that the natives had come under British rule the opportunity ought to be taken to register their condition at the time, not less for scientific than for administrative reasons. The happiness of the natives depended on the way we treated them, and if we were ever to raise them to civilisation - which it must be the great object of every civilised Government to do-we must bear in mind that that could only be done gradually, and by deferring, as far as practicable, to their prejudices, and leading them gently, but gradually, from savagery to that condition of life in which we found our happiness, and in which it was to be hoped they would find theirs.

It is to be hoped that Mr. Hartland's plea will not be ignored by Her Majesty's Government, but that as soon as the condition of the Transvaal and the Orange River Colony should permit, and prior to any legislation affecting the natives, a commission should be appointed to

No. I624, VOL. 63] 
inquire $(a)$ into the customs and institutions of the natives of those States, and $(b)$ into the relations between the natives and European settlers, with power to make recommendations for the purposes above referred to ; such commission to consist, so far as possible, of persons familiar with native life in South Africa, and, in addition, of at least one person, unconnected with South Africa, of recognised eminence in the study of savage customs and superstitions in general.

A. C. HADDON.

\section{ZOOLOGY IN THE WEST INDIES.}

$\mathrm{W}^{\mathrm{B}}$

called attention in our "Notes" of November 29 (NATURE, vol. lxiii. p. II2) to a rumour that the curator of the museum of the Institute of Jamaica, who for close upon six years has laboured with marked success, is about to relinquish his office in the spring; and the receipt of confirmatory evidence forces upon us a comment upon the situation. The gentleman in question was originally appointed in 1896 for a period of three years, which was renewed in 1899 , and during the whole time he has been most assiduous in both the ordinary curatorial and the scientific duties of his office. Under his charge the collections have grown, and by the renewal of old exhibits, and the incorporation of new ones, with a thorough rearrangement of the whole, they have become so materially improved and attractive as to have merited the cordial approval of expert visitors from the home countries and the United States of America. In pure science he has done more; for, while his predecessors were largely content with the mere superficial study of insects, birds and molluscs, he, covering a wider field, has done admirable work in both zoology and anthropology -in the study of the resources of the surrounding sea and of the aboriginal remains on land. He has prod uced a series of memoirs on the indigenous sea-anemones and coral organisms, which rank high in contemporary zoological literature, and which, as will be evident from the brief résumé of his results, which we published in the afore-mentioned note, have done much to clear up a great deal that is perplexing in the study of these organisms. When it is added that the work has necessitated his journeying afield, and that the climatic conditions render research of the kind on modern lines especially difficult, his threatened removal becomes still more mysterious.

Necessity for retrenchment is the alleged cause of it, and by that we presume is meant desire for relief from taxation. If so, the action does not tally with the fact that but a few weeks ago we received, from an authoritative source, a request for advice upon a scheme based on the belief that it might be possible ere long to obtain laboratory accommodation for marine biological work in the Island, in connection with the erection of some hospital buildings in course of construction. The later intelligence which reaches us indicates a sudden change of front for which we desire explanation. To dispense with the services of a curator would be to waste the labours of years, and to bring into reproach an institution now becoming universally recognised as a centre of enlightenment and culture.

From reports to hand, a suspicion arises that the zoological work, as at present carried out under the auspices of the Institute, is not deemed sufficiently economic or adapted to the precise requirements of the island; and that the failure of a recent attempt, on the part of the Caribbean Sea Fisheries' Development Syndicate, to test the resources of certain shallows and banks in the neighbouring seas by means of trawls and long lines, may have had something to do with the situation. If this be so, we can only express our surNo. I 624, voL. 63$]$ prise, for both the area explored and the methods employed were wholly inadequate. Assuming the economic desire, we would point out that the curator of the Jamaica Museum has been by no means neglectful of that phase of his opportunities, and that having recently been commissioned to report upon the Edible Echinus or "sea-egg" of the Barbadoes, in his reply-an interim report, now in circulation--he wisely advocates the determination of its life-history and recourse to artificial propagation and restocking.

Assuming that mere impecuniosity is the real cause of the trouble, we would recommend an appeal to the Home Government and the Colonial Secretary for immediate relief; and the advisability of an affiliation of the establishment with either the recently founded Imperial Agricultural Department, of which the headquarters are at the Barbadoes, or with some other existing institution of an authoritative kind. The time has passed at which work in marine zoology can longer be left to the caprice of mere local administration, and persons content only with an immediate quid pro guo. Experience shows that the scant success which has attended some of the marine zoological work of the past has been due to lack of coordination in observation. What we require for the future, and to ensure that success which even the economist desires, is more, and not fewer, marine observatories, and that these shall be so placed that collective work, properly coordinated, shall be possible over wide areas. Not until every colony having a sea-board, and till at appropriate points round every coast-line there shall be employed a marine zoologist who is a fishery expert, and who shall be provided with a laboratory, a steamboat, a full set of apparatus, and, if possible, a couple of trained assistants, can the desired result be hoped for. We want, and must have, marine stations at all desirable places, and to discourage one already in the making and doing good work is but to court failure and lessen the only chance of success.

As for the Colonies and their marine zoological and museum work, we would fain see the several existing establishments devoted to these placed under the advisorship of the authorities of the British Museum of Natural History, in the manner in which those in botany have so long been under the guidance of the officials at Kew, subject to their power of appeal to the Home Government; and we feel assured that were this already the case the action we herein deplore would never have come about.

Nearly eight years ago zoologists at home, headed by Huxley, directed attention to the resources of the IVest Indian seas and the pressing necessity for their investigation; and the work which has emanated from the museum of the Jamaica Institute has largely realised their expectations. The curator of that museum, moreover, during the period he has held office, has cultivated a healthy alliance with the authorities of the Johns Hopkins University and the members of its Biological School, foremost among marıne zoologists of the North Atlantic, and this has already been productive of mutual gain and cooperative work in the intervening ocean. We now know that materials of prime importance abound in the Jamaica sea, and in the curator of the Jamaica Museum there lives a man, now familiar with these, competent to investigate with advantage both their scientific and economic aspects. His work, upon which we have commented, has been performed with the fullest sympathy and support of the Board of Governors of the institution. His retirement would be followed by their resignation, and chaos would ensue. The proposal to abandon the curatorship of the museum of the Jamaica Institute is retrogade, and it must not be if we, the proud colonisers of the world, are to retain our prestige. 